\title{
Effects of spent brewer's yeast and biological $\beta$-glucans on selected parameters of lipid metabolism in blood and liver in rats
}

\author{
B. Waszkiewicz-Robak ${ }^{1}$ and E. Bartnikowska
}

\author{
Warsaw University of Life Sciences (SGGW), \\ Faculty of Human Nutrition and Consumer Sciences, \\ Department of Functional Foods and Commodity \\ Nowoursynowska 159C, 02-776 Warsaw, Poland
}

(Received 30 May 2008; revised version 11 May 2009; accepted 6 November 2009)

\begin{abstract}
The influence of model atherogenic diet enriched with dried, spent brewer's yeast Saccharomyces cerevisiae or insoluble $\beta$-glucans, isolated from these yeast on selected indices of lipid metabolism was studied in 4 groups of 7-8 growing rats. Animals were fed a control diet (without any supplements) or diet enriched with spent brewer's yeast (daily dose: $50 \mathrm{mg} / \mathrm{kg}$ of body mass) and $\beta$-glucans (daily dose 10 or $100 \mathrm{mg} / \mathrm{kg}$ of body mass) for 6 weeks. The diets supplemented with both additives were more effective in lowering concentration of serum total cholesterol as well as LDL-cholesterol and triacylglycerols in experimental rats than the control diet. In conclusion, feeding rats with dried, spent brewer's yeast or $\beta$-glucans may significantly reduce cholesterol accumulation in liver.
\end{abstract}

KEY WORDS: spent brewer's yeast, Saccharomyces cerevisiae, $\beta$-glucan, cholesterol, LDL, HDL, triacyloglicerols, serum, liver, rats

\section{INTRODUCTION}

In many developed countries the main causes of mortality, especially premature death, are coronary heart disease caused by atherosclerosis. The factors responsible for the development of chronic diseases are numerous and mostly they are divided into two groups: unmodifiable factors (that is, genetic factors, age, sex) and modifiable factors, for example, the pattern of nutrition and the composition of habitual diet. Some food components, such as saturated fatty

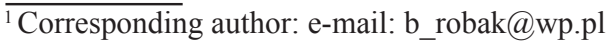


acids, monosaccharides, salt (sodium) consumed, in excess amount can lead to some metabolic disorders and atherosclerosis. Inadequate intakes of certain food components, such as unsaturated fatty acids or water soluble dietary fibre can also provoke the development of chronic diseases.

The results of studies by Korniluk et al. (2006) enabled the formulation of valuable information for nutritionists and dietitians in terms of improving the quality of foods of animal origin by adding unsaturated fatty acids in feeds for animals. Their study showed that the enrichment of diet with isomers of CLA and feeding rats for 4 weeks increased the concentration CLA in the liver and beneficially influenced liver fatty acid profile.

In the 1970 's of the $20^{\text {th }}$ century, Trowell (1972) noted insufficient dietary fibre intakes by people living in developed countries. They demonstrated some mechanisms, whereby dietary fibre can protect from metabolic disorders and chronic diseases. Other studies showed that insoluble components of dietary fibre (pectins, $\beta$-glucans) effectively counteract the prevalence of lipid metabolism disorders and enable their normalization at a moderate level (Bartnikowska, 1999). $\beta$-glucans are components of plant cell walls (the richest sources are oat and barley grains), components of yeast cell walls (especially Saccharomyces cerevisiae and Candida species) and some species of fungi.

Preparation of glucan from spent brewer's yeast has not been reported in the literature. Spent brewer's yeast have been suggested as a possible material for the production of glucan and preparation of yeast extract from spent brewer's yeast would result in crude yeast cell walls as by-product (Suphantharika et al., 1997).

Spent brewer's yeast are a natural product of the brewery that contain immunomodulating components (for example, nucleic acids and manganese), which are currently added to feeds for animals (Klis et al., 2002). The use of dried spent brewer's yeast or $\beta$-glucans obtained from them as bioactive compounds, for example, as functional food should precede the establishment of their mode of action in the body.

Studies in this area have been conducted with the use of the bakery yeast, namely S.cerevisiae, Candida utilis i Kluyveromyces marxianus and pertained their use as source of B group vitamins, dietary fibre and protein (Yoshida et al., 2004).

Some studies in this area concern mainly the immunomodulating properties of yeast and their products. For example, Waszkiewicz-Robak and Karwowska (2004) showed that dried brewer's yeast added to rats' feed in the amount of $0.5 \%$ stabilize primary functions of the immune system. Therefore, it could be expected that the isolation of $\beta$-glucan can also have beneficial effects.

There is scarcity of literature on the influence of supplementation of diet with dried Saccharomyces cerevisiae on lipid metabolism. Wang et al. (1989) 
demonstrated the possibility of blood lowering cholesterol in humans when their diets are supplemented with brewer's yeast, but results of studies by Li (1994) and Trow et al. (2000) did not confirm this. The aim of the present study was to evaluate and to compare the influence of dried, spent brewer's yeast Saccharomyces cerevisiae and insoluble $\beta$-glucans (isolated from these yeast) on selected indices of lipid metabolism in blood and liver in rats.

\section{MATERIAL AND METHODS}

$\beta$-glucan and brewers's yeast preparations

Dried spent brewer's yeast Saccharomyces cerevisiae (containing, \%: protein 43.5 , fat 0.8 , and total carbohydrate 25 ) and commercial $\beta$-glucan, isolated from the yeast cell walls $(92 \% \beta-1,3 / 1,6-\mathrm{D}$-glucan concentration, $1.2 \%$ protein, $<0.6 \%$ of mannans and $<0.5 \%$ chitin), its insoluble form HP (Biolex ${ }^{\circledR}$ - Beta HP (1/3)(1/6)- $\beta$-D-Glucane Powder) were provided by German company LEIBER GmbH - INTER YEAST.

\section{Animals and feeding experiment}

The experimental animals were growing male rats (Wistar) with an initial body weight of about $100 \mathrm{~g}$. Prior to the start of the experiment, animals were given water and commercial, standard rat food LSM ${ }^{\circledR}$ (Fodder Manufacture at Motycz, Poland) ad libitum for 7 days to adapt them to the experimental conditions. Later the animals were randomly divided into 4 groups ( 7 rats in 3 groups and 8 rats in one group) in relation with diet composition: A - control - without $\beta$-glucans or dried yeast; B and C - with $\beta$-glucans; D - with spent brewer's yeast. The average body mass of rats in each group was similar.

The composition of experimental diets is presented in Table 1 . The diets used in this study were isoenergetic $(456-457 \mathrm{kcal} / 100 \mathrm{~g})$. Energy derived from fat, protein and carbohydrates was $40,15.9$ and $44.1 \%$, respectively.

Every day $\beta$-glucan and spent brewer's yeast were weigh in the amounts adequate for each group (see Table 1), mixed with small diet portions ( $5 \mathrm{~g}$ ) and given to each animal individually. After the consumption of this mixture, rats were fed ad libitum diets containing cholesterol. During the whole experimental period (6 weeks) rats were housed in individual cages with $24 \mathrm{~h}$ access to water. The premises, in which the experimental rats were housed had a 12:12 h light cycle with temperature of $21-22^{\circ} \mathrm{C}$ and humidity of $55-65 \%$. 
Table 1. Composition of control and model atherogenic diet enriched with $\beta$-glucan and spent dried brewer's yeast

\begin{tabular}{|c|c|c|c|c|}
\hline \multirow{3}{*}{ Components } & \multicolumn{4}{|c|}{ Diet } \\
\hline & \multirow{2}{*}{$\begin{array}{c}\text { control } \\
\text { A }\end{array}$} & \multicolumn{2}{|c|}{ with $\beta$-glucan } & \multirow{2}{*}{$\begin{array}{l}\text { with spent dried } \\
\text { brewer's yeast D }\end{array}$} \\
\hline & & $\mathrm{B}$ & $\mathrm{C}$ & \\
\hline Wheat starch, g & 49.0 & 49.0 & 48.9 & 48.5 \\
\hline Casein, $\mathrm{g}$ & 20.0 & 20.0 & 20.0 & 20.0 \\
\hline Soya oil, g & 20.0 & 20.0 & 20.0 & 20.0 \\
\hline$\alpha$-cellulose, $g$ & 5.0 & 5.0 & 5.0 & 5.0 \\
\hline DL-methionine, $g$ & 0.3 & 0.3 & 0.3 & 0.3 \\
\hline Choline bitartrate, $g$ & 0.2 & 0.2 & 0.2 & 0.2 \\
\hline Mineral mix, $g$ & 3.5 & 3.5 & 3.5 & 3.5 \\
\hline Vitamin mix, $g$ & 1.0 & 1.0 & 1.0 & 1.0 \\
\hline Cholesterol, g & 1.0 & 1.0 & 1.0 & 1.0 \\
\hline $\begin{array}{l}\beta \text {-glucan } \mathrm{HP} \text { from spent brewer's } \\
\text { yeast, } \mathrm{mg} / \mathrm{kg} \text { of body mass/day }\end{array}$ & - & $10.0^{1}$ & $100.0^{1}$ & - \\
\hline $\begin{array}{l}\text { Dried, spent brewer's yeast, } \\
\text { mg/kg of body mass/day }\end{array}$ & - & - & - & $50.0^{1}$ \\
\hline Per $\mathrm{g} / 100 \mathrm{~g}$ & & & & \\
\hline $\begin{array}{l}\text { protein } \\
\text { fat }\end{array}$ & 18.0 & 18.0 & 18.0 & 18.2 \\
\hline $\begin{array}{l}\text { fat } \\
\text { carbohydrates }\end{array}$ & 20.3 & 20.3 & 20.3 & 20.3 \\
\hline & & & & \\
\hline Energy value, kcal/100 g & 455.5 & 455.5 & 455.5 & 45.3 \\
\hline
\end{tabular}

${ }^{1} \beta$-glucan and spent brewer's yeast were weighed in the amounts adequate for each rat's body mass, then mixed with small diet portions ( $5 \mathrm{~g}$ ) and given to each animal individually. After having eaten, the animals were served diet with cholesterol and water ad libitum

The experimental protocol was approved by the Bioethic Committee in Charge of Animal Welfare at Warsaw University of Life Sciences.

\section{Evaluation of lipid profile}

At the termination of the experiment, all animals were sacrificed (using peritoneal injection of Thiopental). When the rats were in deep narcosis, their blood samples were collected using the puncture of left cardiac ventricle. In additional, liver was taken from killed animals, weighed, and analysed for total lipids and cholesterol content. Blood for lipid determination was allowed to clot. Kept in the cold, serum was centrifuged at $3000 \mathrm{rpm}(\max .60 .000 \mathrm{~g}$ ) for $10 \mathrm{~min}$.

Total cholesterol, HDL-cholesterol and triacylglycerols (TG) in the plasma $(\mathrm{mmol} / \mathrm{l})$ were enzymatically measured with INTEGRA analyzer. The concentrations of LDL cholesterol $(\mathrm{mg} / \mathrm{dl})$ were calculated according to the Friedewald formula (Friedewald et al., 1972). Cholesterol was converted from $\mathrm{mg} / \mathrm{dl}$ to $\mathrm{mmol} / \mathrm{l}$ by multiplying by 0.0259 .

Total lipid content in liver was determined using modified method suggested 
by Folch et al. (1957). Liver cholesterol was extracted and analysed as described by Mazur et al. (1990). Hexane and toluene were used as solvents. Gas chromatography Hewelett-Packard HP 6890N Series GC System Plus with flame ionization detector (FID) and capillary column $30 \mathrm{~m}$ with polar stationary phase was used. Stigmasterol (SIGMA) was used as the standard.

\section{Statistical analysis}

Data are presented as means \pm standard deviation (SD). Obtained results were statistically analysed with STATGRAPHIC programme for Windows (v. 4.1.). The data were analysed using one-way analysis of variance (ANOVA). When a significant $\mathrm{F}$ ratio was found, Tukey's multiple-comparison tests were conducted. Differences were considered significant at $\mathrm{P}<0.05$.

\section{RESULTS}

All experimental animals consumed on average similar amount of diet, ranging from 17.7 to $18.1 \mathrm{~g}$ daily. No significant changes in diet intake $(\mathrm{P}>0.05)$, daily body weight gain and feed efficiency ratio (FER) value were found among rats fed the diets enriched with spent brewer's yeast or $\beta$-glucans (Table 2).

It is worth noting that the addition of spent brewer's yeast or $\beta$-glucan to the diet reduced significantly total serum cholesterol compared to the control diet after feeding animals a basal diet rich in fat (40\% of energy) and cholesterol $(1 \%$ of diet) $(\mathrm{P}=0.0002)$.

Table 2. Body weight (initial and final) and daily body weight gain in rats, FER values and one-way ANOVA (kind of diet as variability source)

\begin{tabular}{|c|c|c|c|c|c|}
\hline Diet & $\begin{array}{c}\text { Initial } \\
\text { weight } \\
\mathrm{g}^{1} \\
\end{array}$ & $\begin{array}{c}\text { Final } \\
\text { weight } \\
\mathrm{g}^{1} \\
\end{array}$ & $\begin{array}{l}\text { Daily body } \\
\text { weight gain } \\
\mathrm{g}^{1} \\
\end{array}$ & $\begin{array}{l}\text { FER } \\
\text { g/day }{ }^{1,2}\end{array}$ & $\begin{array}{c}\text { The average } \\
\text { intake of diet, } \\
\text { g/day }{ }^{1} \\
\end{array}$ \\
\hline Control, $n=7$ & $100.1 \pm 11.3^{\mathrm{a}}$ & $412.3 \pm 21.3^{\mathrm{a}}$ & $6.9 \pm 0.4^{\mathrm{a}}$ & $0.39 \pm 0.03^{\mathrm{a}}$ & $18.1 \pm 04^{\mathrm{a}}$ \\
\hline $\begin{array}{l}\beta \text {-glucan, } 10 \mathrm{mg} / \mathrm{kg} \text { of } \\
\text { body mass } / \text { day, } \mathrm{n}=7\end{array}$ & $100.3 \pm 10.5^{\mathrm{a}}$ & $397.4 \pm 3.0^{\mathrm{a}}$ & $6.6 \pm 0.8^{\mathrm{a}}$ & $0.37 \pm 0.04^{\mathrm{a}}$ & $17.7 \pm 0.7^{\mathrm{a}}$ \\
\hline $\begin{array}{l}\beta \text {-glucan, } 100 \mathrm{mg} / \mathrm{kg} \text { of } \\
\text { body mass } / \text { day, } \mathrm{n}=7\end{array}$ & $100.3 \pm 10.1^{\mathrm{a}}$ & $410.3 \pm 18.0^{\mathrm{a}}$ & $6.9 \pm 0.5^{\mathrm{a}}$ & $0.38 \pm 0.02^{\mathrm{a}}$ & $17.9 \pm 0,4^{\mathrm{a}}$ \\
\hline $\begin{array}{c}\text { Dried, spent brewer's } \\
\text { yeast, } 50 \mathrm{mg} / \mathrm{kg} \text { of } \\
\text { body mass/day, } \mathrm{n}=8\end{array}$ & $100.4 \pm 8.6^{\mathrm{a}}$ & $403.2 \pm 30.9^{a}$ & $6.7 \pm 0.7^{\mathrm{a}}$ & $0.38 \pm 0.03^{\mathrm{a}}$ & $17.9 \pm 0.8^{\mathrm{a}}$ \\
\hline
\end{tabular}


Insoluble $\beta$-glucan at daily dose $100 \mathrm{mg} / \mathrm{kg}$ of body mass was found to have greater influence on lipid metabolism than the other supplements. It is of interest to note that spent brewer's yeast at the daily dose of $50 \mathrm{mg} / \mathrm{kg}$ of body mass and $\beta$-glucans, independently on their daily doses (10 or $100 \mathrm{mg} / \mathrm{kg}$ of body mass) showed similar hypocholesterolaemic activities.

Among all of the examined preparations, lipid metabolism disorders were more efficiently corrected by insoluble $\beta$-glucan at doses of $100 \mathrm{mg} / \mathrm{kg}$ body mass per day $(\mathrm{P}=0.03)$, yet the degree of hipocholesterolaemic action of all the preparations used in the study was similar (Table 3). The high HDL cholesterol/total cholesterol

Table 3. Lipid metabolism parameters in the blood in rats

\begin{tabular}{|c|c|c|c|c|c|}
\hline \multirow[b]{2}{*}{ Diet } & \multirow{2}{*}{$\begin{array}{c}\text { Total } \\
\text { cholesterol, } \\
\text { mmol/1 }\end{array}$} & \multicolumn{2}{|c|}{ Cholesterol fractions, $\mathrm{mmol} / \mathrm{l}$} & \multirow[b]{2}{*}{$\mathrm{TG}, \mathrm{mmol} / \mathrm{l}$} & \multirow{2}{*}{$\begin{array}{c}\text { HDL } \\
\text { /total } \\
\text { cholesterol }\end{array}$} \\
\hline & & HDL & LDL & & \\
\hline Control, $n=7$ & $3.79 \pm 0.13^{\mathrm{a}}$ & $1.58 \pm 0.15^{\mathrm{a}}$ & $1.80 \pm 0.12^{\mathrm{a}}$ & $0.90 \pm 0.07^{\mathrm{a}}$ & $0.42 \pm 0.03^{\mathrm{a}}$ \\
\hline $\begin{array}{r}\beta \text {-glucan, } 10 \mathrm{mg} / \mathrm{kg} \text { of } \\
\text { body mass } / \text { day, } \mathrm{n}=7\end{array}$ & $3.20 \pm 0.38^{\mathrm{bc}}$ & $1.55 \pm 0.15^{\mathrm{ab}}$ & $1.33 \pm 0.25^{b}$ & $0.74 \pm 0.02^{\mathrm{b}}$ & $0.49 \pm 0.02^{\mathrm{b}}$ \\
\hline $\begin{array}{c}\beta \text {-glucan, } 100 \mathrm{mg} / \mathrm{kg} \text { of } \\
\text { body mass/day, } \mathrm{n}=7\end{array}$ & $2.82 \pm 0.38^{\mathrm{c}}$ & $1.47 \pm 0.19^{\mathrm{ab}}$ & $1.10 \pm 0.19^{c}$ & $0.76 \pm 0.04^{b}$ & $0.52 \pm 0.03^{\mathrm{c}}$ \\
\hline $\begin{array}{c}\text { Dried, spent brewer's } \\
\text { yeast, } 50 \mathrm{mg} / \mathrm{kg} \text { of } \\
\text { body mass/day, } \mathrm{n}=8\end{array}$ & $2.97 \pm 0.36^{\mathrm{bc}}$ & $1.39 \pm 0.13^{b}$ & $1.09 \pm 0.26^{\mathrm{bc}}$ & $0.66 \pm 0.09^{\mathrm{b}}$ & $0.47 \pm 0.03^{b}$ \\
\hline $\begin{array}{l}\mathrm{SEM}^{2} \\
\mathrm{P}^{3 /}\end{array}$ & $\begin{array}{l}0.03 \\
0.0002\end{array}$ & $\begin{array}{l}0.09 \\
0.13\end{array}$ & $\begin{array}{l}0.002 \\
0.001\end{array}$ & $\begin{array}{l}0.007 \\
0.004\end{array}$ & $\begin{array}{l}0.03 \\
0.001\end{array}$ \\
\hline
\end{tabular}

$\mathrm{n}$ - number of animals in each group; ${ }^{1 \mathrm{a}}$ verage $(\overline{\mathrm{x}}) \pm$ standard deviation (SD); ${ }^{2} \mathrm{SEM}$ - standard error of the mean; ${ }^{3 /} \mathrm{ANOVA}, \mathrm{P}<0.05$; average values sharing the same superscript are not statistically different

Table 4. The content of total lipids and cholesterol in livers of control rats, and rats fed atherogenic diet enriched with $\beta$-glucan and spent dried brewer's yeast

\begin{tabular}{|c|c|c|c|c|}
\hline \multirow[b]{2}{*}{ Diet } & \multicolumn{2}{|c|}{ Total lipids } & \multicolumn{2}{|c|}{ Total cholesterol } \\
\hline & $\begin{array}{l}\mathrm{g} / 100 \mathrm{~g} \text { of wet } \\
\text { liver tissue }\end{array}$ & $\begin{array}{l}\mathrm{g} / 100 \mathrm{~g} \text { of dry } \\
\text { mass of liver }\end{array}$ & $\begin{array}{l}\mathrm{mg} / 1 \mathrm{~g} \text { of wet } \\
\text { liver tissue }\end{array}$ & $\mathrm{mg} / \mathrm{g}$ of lipids \\
\hline Control, $n=7$ & $20.9 \pm 2.8^{\mathrm{a}}$ & $47.3 \pm 1.3^{\mathrm{b}}$ & $82.5 \pm 7.5^{\mathrm{a}}$ & $432.1 \pm 23.7^{\mathrm{a}}$ \\
\hline $\begin{array}{l}\beta \text {-glucan, } 10 \mathrm{mg} / \mathrm{kg} \text { of } \\
\text { body mass/day, } \mathrm{n}=7\end{array}$ & $18.4 \pm 1.9^{\mathrm{a}}$ & $42.5 \pm 3.9^{\mathrm{ab}}$ & $66.0 \pm 1.1^{\mathrm{b}}$ & $361.4 \pm 28.1^{\mathrm{b}}$ \\
\hline $\begin{array}{r}\beta \text {-glucan, } 100 \mathrm{mg} / \mathrm{kg} \text { of } \\
\text { body mass/day, } \mathrm{n}=7\end{array}$ & $18.7 \pm 3.4^{\mathrm{a}}$ & $39.1 \pm 3.7^{\mathrm{a}}$ & $65.1 \pm 5.4^{b}$ & $348.3 \pm 38.8^{b}$ \\
\hline $\begin{array}{l}\text { Dried, spent brewer's } \\
\text { yeast, } 50 \mathrm{mg} / \mathrm{kg} \text { of } \\
\text { body mass/day, } \mathrm{n}=8\end{array}$ & $19.1 \pm 2.7^{\mathrm{a}}$ & $43.4 \pm 4.4^{\mathrm{ab}}$ & $65.1 \pm 5.0^{\mathrm{b}}$ & $369.1 \pm 30.1^{\mathrm{ab}}$ \\
\hline $\mathrm{SEM}^{2}$ & 0.13 & 0.254 & 0.37 & 2.68 \\
\hline $\mathrm{P}^{3}$ & 0.42 & 0.007 & 0.02 & 0.049 \\
\hline
\end{tabular}

$\overline{\mathrm{n} \text { - number of animals in each group; }{ }^{1} \text { average }(\overline{\mathrm{x}}) \pm \text { standard deviation }(\mathrm{SD}) ;{ }^{2} \mathrm{SEM} \text { - standard error }}$ of the mean; ${ }^{3}$ ANOVA, $\mathrm{P}<0.05$; average values sharing the same superscript are not statistically different 
ratio maintained in the rats on atherogenic diet supplemented with $\beta$-glucan HP at doses of $100 \mathrm{mg} / \mathrm{kg}$ body mass per day, confirms it's great effectiveness in normalizing the disorders of lipid metabolism induced via gastrointestinal track (Table 3).

Moreover, both supplements significantly decreased the level of TGtriacylglycerols in serum after feeding the animals the model atherogenic diet compared to those fed control diet $(\mathrm{P}=0.004)$. Spent brewer's yeast and $\beta$-glucans at both doses, reduced cholesterol accumulation in the liver of the experimental animals $(\mathrm{P}=0.02)$ (Table 4).

\section{DISCUSSION}

In 1963 De Groot et al. (1963) was the first to demonstrate experimentally that diet enriched with oat flakes decreased total serum cholesterol in healthy people. Other studies (Bartnikowska and Lange, 2000) confirmed the cholesterol lowering effects of oat products in patients with lipid metabolism disorders.

In order to explain, in details which component of oat product is responsible for its hypocholesterolaemic activity many experiments were conducted on animals. Newmann et al. (1992) fed chickens diet enriched with one of two oat varieties containing different $\beta$-glucans concentrations. The chickens fed the oat diet with higher $\beta$-glucans content have considerably lower cholesterol concentration compared to those fed diet with lower $\beta$-glucans content. $\beta$-glucans derived from cereal grains seem to be too expensive. Therefore, the search for new sources of these components was focused on dried, spent brewer's yeast Saccharomyces cerevisiae. From healthy point of view dried, spent brewer's yeast have been recognized as a safe product by FDA (Food and Drug Administration) and have been placed on GRAS list with number 172.896 (FDA, 2006), with the allowance of its use as a supplement providing protein, vitamin $\mathrm{B}$ complex, and recommended at the daily dose from 7 to $30 \mathrm{~g} /$ day in human diet (Roberts et al., 2001).

Spent brewer's yeast are widely used as a feed additive in improving growth and good health status in animals (Ortuňo et al., 2002). They are also used as a raw material to obtain biomass, yeast extracts, vitamins and enzymes (Thammakiti et al., 2004). Their use in human nutrition is limited by purine compounds and nucleic acids, and their uncontrolled high intake could cause elevation of the concentration of uric acid in blood and increase the risk of arthritis. In the 1970's of $20^{\text {th }}$ doses of nucleic acid in the diet that do not pose a problem were established at the level of $2 \mathrm{~g} /$ day, which corresponds to 30-50 g intake of dry yeast/day (Schulz and Oslage, 1976). 
Most of studies carried out on animals using diets enriched with spent brewer's yeast and bakery yeast concerned their effects on the immune system. There is scarcity of data about the impact of these yeast on lipid metabolism.

The diet supplemented with spent brewer's yeast at daily dose of $50 \mathrm{mg} / \mathrm{kg}$ body mass resulted in improving lipid metabolism disorders among animals fed atherogenic diet. This effect was probably a consequence of bioactive compounds present in yeast, that is, manic, $\beta$-glucans or chitin. Saccharomyces cerevisiae yeast contain $\beta$-glucans at high concentration (6-7.7\%) in cell walls. Due to physiochemical properties of $\beta$-glucans such as solubility, viscosity or ability to form gel are considered as beneficial food components for health protection (Charalampopoulos et al., 2002). $\beta$-glucans, in its soluble form having more viscous solutions showed better hypocholesterolaemic effect.

In the present work, the used $\beta$-glucans HP or dried, spent brewer's yeast were found to be insoluble or partly soluble in water, forming instable, non-viscous solutions with tendency to sediment. Therefore, it could be suggested that their modification by improving their solubility and increasing their viscosity could result in their higher beneficial hypocholesterolaemic effect.

In the present study it was found that the application of dried, spent brewer's yeast $S$. cerevisiae in the amount of $0.5 \%$ brought about an improvement in the disorders of lipid metabolism.

Yoshida et al. (2004) showed hypocholesterolaemic activity of spent brewer's yeast in male Wistar rats at the concentration of $10 \%$ in the diet. In contrast, brewer's yeast and baker's yeast, which have been predominantly used for food, did not exhibit hypocholesterolaemic activity even when administered at concentration of $10 \%$.

The cholesterol lowering properties of yeast in rats may be due to the action of prebiotics present in them (Blaut, 2002) or considerably high amount of squalene in yeast lipids (Blagović et. al., 2001).

\section{CONCLUSIONS}

The diets enriched with dried, spent brewer's yeast Saccharomyces cerevisiae and $\beta$-glucans isolated from these yeast showed effective hypocholesterolaemic properties counteracting lipid metabolism disorders. The model atherogenic diet reduced statistically significant total serum cholesterol, its LDL (low density lipoproteins) fraction and triacylglycerols concentration in rats, fed this diet compared to control group.

Taking the above facts into consideration and the results obtained in this work, it seems that dried, spent brewer's yeast $S$. cerevisiae, containing both 
$\beta$-glucan and squalene, may be a good ingredient to use as a diet supplement in lowering total cholesterol, triacylglycerols, and correcting disorders of lipid metabolism.

\section{REFERENCES}

Bartnikowska E., 1999. The role of dietary fiber in the prevention of lipid metabolism disorders. In: S.S. Cho, L. Prosky, M. Dreher (Editors). Complex Carbohydrates in Foods. Marcel Dekker, NY, pp. 53-62

Bartnikowska E., Lange E., 2000. The dietary value of oat products and their influence on serum total cholesterol and glicemia after meal (in Polish). Food Nutr. Sci. 22, 18-36

Blagović B., Rupčić J., Mesarić M., Georgiú K., Marić V., 2001. Lipid composition of brewer's yeast. Food Technol. Biotechnol. 39, 175-181

Blaut M., 2002. Relationship of prebiotics and food to intestinal microflora. Eur. J. Nutr. 41, 11S$16 \mathrm{~S}$

Charalampopoulos D.R., Wang R., Pandiella S.S., Webb C., 2002. Application of cereals and cereal components in functional foods: a review. Int. J. Food Microbiol. 79, 131-141

De Groot A.P., Luyken R., Pikaar N.A., 1963. Cholesterol-lowering effects of rolled oats. Lancet II, 303-304

FDA U.S. (Food and Drug Administration), 2006. Food Additive Status List. Center for Food Safety and Applied Nutrition; Office of Food Additive Safety. (http://www.cfsan.fda.gov/ acrobat/opaappa.pdf) (28.03.2008)

Folch J., Lees M., Stanley G.H.S., 1957. A simple method for the isolation and purification of total lipid from animal tissues. J. Biol. Chem. 226, 497-509

Friedewald W.T., Levy R., Fredrickson D.S., 1972. Estimation of the concentration of low-density lipoprotein cholesterol in plasma, without use of the preparative ultracentrifuge. Clin. Chem. 18, 499-502

Klis F.M., Mol P., Hellingwerf K., Brul S., 2002. Dynamics of cell wall structure in Saccharomyces cerevisiae. FEMS Microbiol. Rev. 26, 239-256

Korniluk K., Czauderna M., Kowalczyk1 J., Mieczkowska A., Taciak M., Leng L'., 2006. Influence of dietary conjugated linoleic acid isomers and selenium on growth, feed efficiency, and liver fatty acid profile in rats. J. Anim. Feed Sci. 15, 131-146

Li Y.C., 1994. Effects of brewer's yeast on glucose tolerance and serum lipids in Chinese adults. Biol. Tr. Elem. Res. 41, 341-347

Mazur A., Remesy C., Gueux E., Levrat M.A., Demigne C., 1990. Effects of diets rich in fermentable carbohydrates on plasma lipoprotein levels and on lipoprotein catabolism in rats. J. Nutr. 120, 1037-1045

Newmann R.K., Klopfenstein C.F., Newman C.W., Guritno N., Hofer P.J., 1992. Comparison of the cholesterol-lowering properties of whole barley, oat bran, and wheat red dog in chicks and rats. Cereal Chem. 69, 240-244

Ortuňo J., Cuesta A., Rodriguez A., Esteban M.A., Meseguer J., 2002. Oral administration of yeast, Saccharomyces cerevisiae, enhances the cellular innate immune response of gilthead seabream (Sparus aurata L.). Vet. Immunol. Immunopathol. 85, 41-50

Roberts A.J., O’Brien M.E., Subak-Sharoe G., 2001. Nutraceuticals. The Complete Encyclopedia of Supplements, Herbs, Vitamins, and Healing Foods. The Official American Nutraceutical Association Guide. New York, pp. 273-275 
Schulz, E., Oslage H.J., 1976. Composition and nutritive value of single-cell protein (SCP). Anim. Feed Sci. Tech. 1, 9-24

Suphantharika M., Varavinit S., Shobsngob S., 1997. Determination of optimum conditions for autolyzed yeast extract production. Asian J. Sci. Technol. Develop. 14, 21-28

Thammakiti S., Suphantharika M., Phaesuwan T., Verduyn C., 2004. Preparation of spent brewer's yeast $\beta$-glucans for potential applications in the food industry. Int. J. Food Sci. Tech. 39, 21-29

Trow L.G., Lewis J., Greenwood R.H., Sampson M.J., Self K.A., Crews H.M., Fairweather-Tait S.J., 2000. Lack of effect of dietary chromium supplementation on glucose tolerance, plasma insulin and lipoprotein levels in patient with type 2 diabetes. Int. J. Vitam. Nutr. Res. 70, 14-18

Trowell H., 1972. Ischemic heart disease and dietary fiber. Amer. J. Clin. Nutr. 25, 926-932

Wang M.M., Fox E.A., Stoeker B.J., Menendez C.E., Chan S.B., 1989. Serum cholesterol of adults supplemented with brewer's yeast or chromium chloride. Nutr. Res. 9, 989-998

Waszkiewicz-Robak B., Karwowska W., 2004. Brewer's yeast as an ingredient enhancing immunity. Pol. J. Food Nutr. Sci. 13, SI 2, 85-87

Yoshida Y., Yokoi W., Wada Y., Ohishi K., Ito M., Sawada H., 2004. Potent hypocholesterolemic activity of the yeast Kluyveromyces marxianus YIT 8292 in rats fed a high cholesterol diet. Biosci. Biotechnol. Biochem. 68, 1185-1192 